\title{
The Last Cyclist (Poslední cyklista)
}

Author: Karel Švenk

First Published: 1961

Theatre Adaptations: Theresienstadt (1944); Prague, Theatre Rokoko (1961); Cedar Grove, Temple Sholom of West Essex (1995); St. Paul, Czech and Slovak Cultural Centre (2009); Mexico City, Theatre Thespis (2012); New York, The West End Theater (2013); Scotch Plains, NJ, Congregation Beth Israel (2014); Milwaukee, Nancy Kendall Theater (2019).

About the Author: Karel Švenk, written also Karl Schwenk (1917-1945), came from a Czech-Jewish family, his father was a tailor. Švenk took part in the musically dramatic avant-garde group "Club of Unrecognised Talents” (Klub zapadlých talentů) in Prague from 1934 to 1938. In November 1941, he was deported to the Theresienstadt Ghetto, and was among the young Jewish men sent to prepare the previously non-Jewish camp for the Jewish prisoners (so-called Aufbaukommando). He was the initiator of cultural activities in Theresienstadt, as a cabaret artist, comedian, songwriter and playwright. He wrote and staged the satirical plays Long Live the Life! (1943) and The Last Cyclist (1944). The song Anything Goes! also called Theresienstadt March (Všechno jde! or Terezínský pochod), his best-known music composition, became a secret ghetto anthem. Another of Švenk's songs Why Does the White Man Sit in the Front of the Bus was preserved by the musician and Theresienstadt survivor George Horner (it was later arranged by David Post and recorded by the Hawthorne String Quartet). In October 1944, Švenk was sent to Auschwitz, then briefly to a factory, and later died in a cattle wagon on a subsequent transport to Mauthausen-Gusen concentration camp. A different source stated that he was shot by a Nazi soldier on a forced march.

\section{Content and Interpretation}

The play was written in the Theresienstadt Ghetto in 1944 and Švenk with his collaborators (among others, the stage designer František Zelenka and the actor Jiři Süssland Cajlajs) prepared its performance. Nevertheless, after its dress rehearsal, the play, full of satirical hints at the Nazis and Nazi ideology, was forbidden by the Jewish self-administration for fear of persecutions. According to witnesses, it was secretly performed in the attics of Theresienstadt barracks (Jedličková, 2014, p. 185).

The manuscript of the play has only been preserved in fragments. The Last Cyclist was officially premiered in 1961 (Theatre Rokoko in Prague) while the play was reconstructed by witnesses (the actor Jana Šedová that participated in the Theresienstadt performance) and newly adapted (Darek Vostřel). New songs were written by Ivo Rožek, Ivan Vyskočil and Darek Vostřel. 
The plot is inspired by the anecdote according to which the Jews and the cyclists cause everything that is bad. "The Jews and the cyclists are responsible for all of our misfortunes!" "Why the cyclists?" "And why the Jews?"

The work takes place in an unknown land where the inmates of a mental asylum escape and take over the outside world. Because the head of the madhouse rides a bicycle, they hound, oppress or kill everyone who rides a bicycle and anyone who has ever had anything to do with cyclists for many generations back. The main character is the Jew Bořivoj Abeles, a small shopkeeper and Chaplinesque anti-hero. (In the original version in Theresienstadt, he was played by Karel Švenk.) Due to being the last remaining cyclist, he is chased. He escapes several times but is caught in the end. When citizens rebel against hunger, Abeles is charged as a culprit and sentenced to being shot in a rocket to the Moon. His last wish is to smoke a cigar and to see his girlfriend Mánička (Mary). While smoking his last cigar, he unintentionally ignites the rocket thereby launching the dictator as well as all the lunatics to the Moon. Borrivoj Abeles runs out and tells the spectators, “Go home! You are free!” but Mánička adds: "Only on the stage is there a happy ending. Out there, where you are, our troubles continue”.

\title{
Main Topics and Problems
}

The Last Cyclist mocked the Nazi propaganda and the traditional antisemitic stereotypes. It was probably the most courageous production written and performed in Theresienstadt.

Dictator Ms Narcissus: All bikes owners will wear a C on their coats. [...] They are forbidden under the penalty of death to eat, drink, read, write or to sleep. (Švenk, 1961, p. 38)

\begin{abstract}
Krysa (The Rat): Brothers! You are rightly embarrassed by the lack of food. [...] Whose fault is it? The common cyclist! Just look at him! His devilish brain has been making plans about how to enslave and destroy you. Whose fault is it that a bloody fight is unleashed? The common cyclist! His greedy hands have gambled on the Stock Exchange and he has secretly hoarded huge piles of provisions. Whose fault is the lack of smokes? The common cyclist. His protruding ears have listened to hostile speech and his blubbery lips have spreaded these bunks. [...] The cyclists have been riding in our country and their perverse eyebrows have seduced our girls. Whose fault is it that marriages have been broken and families have been wrecked! The common cyclist! (Šormová, 1973, p. 48)
\end{abstract}

Today it is impossible to know how closely Jana Šedová and Darek Vostřel reconstructed the script in accord with Švenk's original. In any case, in 1961, the play was also adapted and updated, for instance the ending. Abeles is caged in a zoo as the last specimen of a cyclist. A rebellion against the violent regime breaks out in the country. The Rat is arrested and sentenced to death. It seems Bořivoj Abeles is finally free. Nevertheless, the danger of racism and xenophobia does not disappear. 


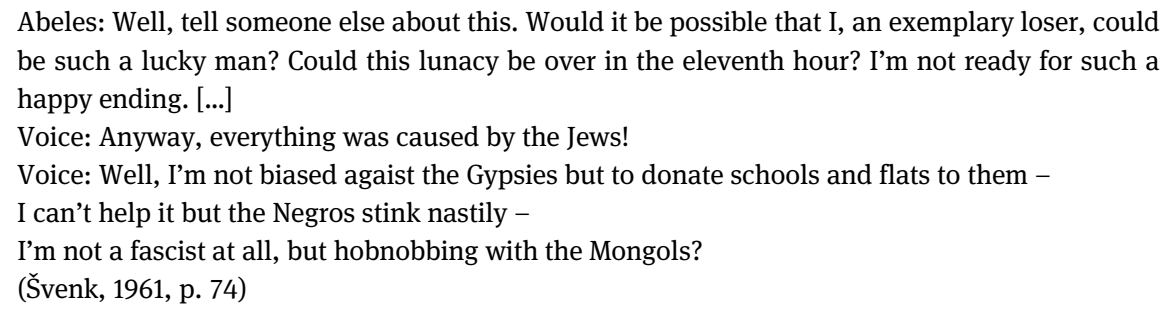

The American adaptation was created by Naomi Patz in collaboration with Lisa Peschel who is a published editor and critic of plays and cabarets from the Ghetto Theresienstadt (Peschel, 2014). The work became a play within a play. The open dress rehearsal ended abruptly with the announcement of an impending deportation to the East. This adaptation also included Švenk's The Theresienstadt March. This is how the "spiritual resistance" of Jews in Theresienstadt to the Nazis was emphasised.

\section{Cited Works}

Jedličková, B. (2015). Jana Šedová-Popperová. In: B. Jedličková, ed., Ženy na rozcestí. Divadlo a ženy okolo něj 1939-1945. Praha: Academia, pp. 171-191. Švenk, K. (1961). Poslední cyklista. Praha: Divadlo Rokoko. (Typescript saved in Theatre Institute in Prague).

\section{Further References}

Genzlinger, N. (2013). Satire Born in the Face of Horror. New York Times, 02.06. Holý, J. (2016). Divadelní a literární činnost v terezínském ghettu. In: J. Holý, ed., Cizí i blízcí. Židé, literatura, kultura v českých zemích ve 20. století. Praha: Akropolis, pp. 332-336. Karas, J. (1990). Music in Terezin: 1941-1945. Stuyvesant: Pendragon. Peschel, L. (2014). Introduction. In: L. Peschel, ed., Performing Captivity, Performing Escape: Cabarets and Plays from the Terezin/Theresienstadt Ghetto. London/New York/Calcutta: Seagull Books, pp. 1-35. Rovit, R. (1999). Introduction. In: R. Rovit, A. Goldfarb, eds., Theatrical Performance during the Holocaust: Texts, Documents, Memoirs. Baltimore, London: The Johns Hopkins University Press, pp. 1-10 Rovit, R. (2000). A Carousel of Theatrical Performances in Theresienstadt. In: A. D. Dutlinger, ed., Art, Music and Education as Strategies of Survival: Theresienstadt 1941-45. New York/London: Herodias, pp. 122-143. Šedová, J. (1965). Terezínské divadlo. In: F. Černý, ed., Theater/Divadlo. Vzpomínky českých divadelníků na německou okupaci a druhou světovou válku. Praha: Orbis, pp. 229-239. Šormová, E. (1973). Divadlo v Terezíně 1941-1945. Ústí nad Labem: Severočeské nakladatelství. Šormová, E. (1997). Divadlo v Terezíně. In: M. Kárný, M. Kárná, eds., Terezínské studie a dokumenty. Praha: Academia, pp. 242-250. Urbanová, A. (1961). Poslední cyklista v Rokoku. Večerní Praha, 9. 6., p. 3.

The Last Cyclist. Reconstructed and Reimagined by Naomi Patz. Available at: http:// www.thelastcyclist.com/about-terezin/remembering-karel-svenk/ [Accessed: 11.05. 2019] 
Naomi Patz, Lisa Peschel: The Last Cyclist in Minnesota. Available at: http://www. bterezin.org.il/120869/The-Last-Cyclist-in-Minnesota [Accessed: 28.05.2015] Performing in Mexico City Available at: http://www.mzv.cz/mexico/cz/kultura_a skolstvi/divadelni_nastudovani_hry_karla_svenka.html [Accessed: 28.11.2015] Song Why Does the White Man Sit in the Front of the Bus? Available at: https://www. tmfgala.org/george-horner.html [Accessed: 14.05.2019]

The Last Cyclist. Congregation Beth Israel. Available at: https://www.youtube.com/ watch?v=AH5cIwwvz_U [Accessed: 15.05.2019]

$\mathrm{JH}$ 